\title{
Audit Kepastian Kualitas untuk Menilai Efektivitas Sistem Manajemen Mutu ISO 9001:2008 di UPT Perpustakaan Universitas Jember
}

\section{(Audit Quality to Evaluate the Effectiveness of Quality Management System ISO 9001:2008 in UPT Perpustakaan Universitas Jember)}

\author{
Septarina Prita, Jean Suha Theresia Br. Aritonang, dan Wasito \\ Jurusan Akuntasi, Fakultas Ekonomi, Universitas Jember (UNEJ) \\ Jln. Kalimantan 37, Jember 68121 \\ E-mail: yunania2006@yahoo.co.id
}

\begin{abstract}
Abstrak
Perpustakaan adalah pelayanan, oleh sebab itu UPT Perpustakaan Universitas Jember berkomitmen untuk terus meningkatkan pelayanan yang diberikan kepada pemustaka dengan mengimplementasikan sistem manajemen mutu ISO 9001:2008. Alat untuk menilai efektivitas sistem manajemen mutu ISO 9001:2008 yang telah diimplementasikan adalah audit kualitas secara berkala tiap tahunnya oleh Badan Penjamin Mutu (BPM). Audit kepastian kualitas dilakukan dengan wawancara, membagikan kuesioner kepada tiap kepala bidang dan melakukan observasi untuk melihat apakah kriteria telah sesuai dengan kenyataan. Audit sistem kepastian kualitas yang dilakukan di UPT Perpustakaan Universitas Jember untuk menilai efektivitas penerapan SMM ISO 9001:2008 menghasilkan beberapa temuan minor dan mayor. Temuan minor didapati di bidang Pembinaan Koleksi dan bidang Gugus Penjamin Mutu, sedangkan temuan mayor ditemukan di bidang Sirkulasi, bidang Pengembangan dan Kerjasama dan bidang Layanan Perujukan dan Koleksi Khusus. Temuan mayor ini artinya manajemen harus memberikan perhatian lebih akan penerapan sistem manajemen mutu di bidang tersebut karena temuan tersebut dapat mempengaruhi kesesuaian proses dan produk, dan dapat mempengaruhi mutu layanan perpustakaan. Temuan minor, artinya temuan tersebut tidak mempengaruhi mutu dari produk atau layanan yang diberikan perpustakaan, dan temuan tersebut seringkali dikarenakan kesalahan manusia. Meskipun tidak mempengaruhi mutu produk atau layanan namun temuan minor juga harus didokumentasikan dan ditindak lanjuti agar kejadian serupa tidak terulang kembali di masa yang akan datang.
\end{abstract}

Kata Kunci: Audit Kualitas, ISO 9001:2008, Perpustakaan, Sistem Manajemen Mutu

\begin{abstract}
Library is all about service, therefore UPT Perpustakaan Universitas Jember commited to always do a continuous improvement on their service by implying quality management systems ISO 9001:2008. Tools to evaluate the effectiveness of quality management systems is quality audit which is held by Badan Penjamin Mutu (BPM) and performed annually. Quality audit performed by interviewing respondents, ask the respondents to filling in the questionnaires, and the last method is observing the library activity, and analyzes if the reality meets the standards set by the UPT Perpustakaan itself. There are 3 types of finding resulted by quality audit avtivity, they are cathegorized as observative finding, minor finding and mayor finding. Minor findings have been found in Pembinaan Koleksi's sector and Gugus Penjamin Mutu's sector whilst the mayor findings coming from Sirkulasi's sector, Pengembangan dan Kerjasama's sector and Layanan Perujukan dan Koleksi Khusus's sector. Mayor findings means that management should give more attention to the implimentation of quality management system which is implied to these sectors because the findings can influence the conformity between the processes and the products offered so that those will affect the services's quality given by the library. Minor findings means that finding will not influences the quality of the services, and generally human error is the cause of that findings. But although it will not influences the quality of the services, the minor findings still needs to be documented and need a correction action to correct the findings so that in the future, the management can prevent similar findings to ever occured again.
\end{abstract}

Keywords: ISO 9001:2008, Library, Quality Audit, Quality Management Systems

\section{Pendahuluan}

Perpustakaan menurut Nasution $(1990,139)$ adalah pelayanan. Definisi tersebut menggambarkan bahwa keseluruhan perpustakaan adalah sebuah pelayanan dan menuntut perpustakaan untuk terus meningkatkan efektivitasnya dalam pelayanan dan mutu perpustakaan. UPT Perpustakaan Universitas Jember mengimplementasikan Sistem Manajemen Mutu (SMM) ISO $9001: 2008$ dengan tujuan untuk meningkatkan kualitas pelayanan, pengelolaan dan pengendalian. Apabila pihak manajemen telah melakukan tugasnya secara efektif maka manajemen akan memberikan hasil kerja yang bermutu. UPT Perpustakaan Universitas Jember membutuhkan waktu satu tahun untuk mempersiapkan dokumen mutu, memenuhi persyaratan sistem manajemen mutu dan memperoleh sertifikat ISO 9001:2008 pada tahun 2009. Akan tetapi perolehan sertifikat ISO bukanlah tujuan akhir melainkan adalah sebuah proses untuk mencapai tujuan yaitu mencapai standar yang telah ditetapkan hingga tercapai kepuasan pelayanan dari sudut pemustaka. Implementasi SMM ISO 9001:2008 membutuhkan instrumen untuk menilai efektivitas penerapannya, instrumen tersebut adalah audit mutu yang dilakukan secara berkala.

Audit mutu adalah salah satu cara yang efektif untuk mensinyalir atau mendeteksi dini dan memperbaiki kesalahan-kesalahan yang akan terjadi dimasa depan yang dilakukan divisi manajemen mutu. Apabila kemungkinan terjadi kesalahan berkurang, resiko dan keluhan dari 
pengguna layanan dapat diminimalisir sehingga visi dan misi organisasi dapat tercapai. Audit mutu hanya menguji segi efektifitas dalam penerapan ISO 9001 : 2008 dikarenakan yang diuji adalah hasil akhir atau ukuran dari output atas pemenuhan kualifikasi atau standar yang telah ditetapkan.

\section{Metode}

\section{Jenis Penelitian}

Jenis penelitian yang digunakan dalam penelitian ini adalah penelitian kualitatif. Penelitian ini menggunakan metode penelitian deskriptif. Metode pengumpulan data yang sering digunakan dalam penelitian dengan metode deskriptif adalah metode survei, yaitu teknik pengumpulan dan analisis data berupa opini dari subyek yang diteliti melalui tanya-jawab. Penelitian ini menggunakan pendekatan studi kasus. Pendekatan studi kasus adalah penelitian dengan karakteristik masalah yang berkaitan dengan latar belakang dan kondisi saat ini dari subyek yang diteliti, serta interaksinya dengan lingkungan.

\section{Jenis Data dan Teknik Pengumpulan Data}

Sumber data yang digunakan untuk penelitian ini adalah data primer dan data sekunder. Data primer merupakan data yang diperoleh atau dikumpulkan langsung di lapangan oleh orang yang melakukan penelitian atau bersangkutan yang memerlukannya (Hasan 2002:82). Sementara data sekunder adalah data penelitian yang diperoleh peneliti secara tidak langsung melalui media perantara atau diperoleh dan dicatat oleh pihak lain (Indriantoro dan Supomo, 2009:147).

Dalam penelitian ini teknik pengumpulan data dilakukan dengan survei pendahuluan, survei lapangan( wawancara, kuesioner, pengamatan, dokumentasi). Review dan pengujian pengendalian manajemen dilakukan di beberapa bidang yang ada di UPT Perpustakaan Universitas Jember, yaitu :

a.Bidang Pembinaan Koleksi

b.Bidang Pengembangan dan Kerjasama

c. Bidang Sirkulasi dan Tandon

d. Bidang Layanan Perujukan dan Koleksi Khusus

Pada tahap ini temuan-temuan data dianalisis dengan menggunakan kriteria (criteria), sebab (causes), dan akibat (effects).

\section{Kriteria (criteria)}

Kriteria adalah standar (norma) yang menjadi pedoman bertindak bagi setiap individu dan kelompok dalam organisasi (Bayangkara, 2014: 64). Kriteria yang dimaksud adalah tujuan dan kebijakan yang disusun oleh UPT Perpustakaan Universitas Jember.

\section{Sebab (causes)}

Sebab adalah pelaksanaan prosedur-prosedur dan pengelolaan dalam organisasi yang menyebabkan kondisi pelayanan saat ini di UPT Perpustakaan Universitas Jember.

\section{Akibat (effects)}

Sesuatu yang harus ditanggung atau dinikmati perusahaan karena terjadinya perbedaan aktivitas yang seharusnya dilakukan (berdasarkan kriteria) dengan aktivitas actual yang terjadi di lapangan (dilakukan oleh setiap komponen dalam organisasi).

Peneliti membandingkan kriteria dengan penyebab untuk mengukur tingkat efektifitas pengelolaan fungsi kualitas pada UPT Perpustakaan Universitas Jember. Pengelolaan fungsi kualitas dapat dikatakan telah dikelola secara efektif apabila kriteria dapat dicapai dalam penyebab dan tidak ditemukan kelemahan atau perbedaan dalam penyebab.

\section{Pemeriksaan Keabsahan Data}

Peneliti menggunakan teknik pemeriksaan keabsahan data triangulasi. Menurut Moleong (2015:330) triangulasi adalah teknik pemeriksaan keabsahan data yang memanfaatkan sesuatu yang lain di luar data itu untuk keperluan pengecekan atau sebagai pembanding terhadap data itu. Peneliti memutuskan untuk menggunakan teknik triangulasi dengan memanfaatkan penggunaan sumber. Triangulasi dengan sumber menurut Paton (1987:331) dalam Moleong (2015:330) berarti membandingkan dan mengecek balik derajat kepercayaan suatu informasi yang diperoleh melalui waktu dan alat yang berbeda dalam penelitian kualitatif.

\section{Hasil dan Pembahasan}

\section{Hasil}

Hasil audit kualitas yang telah dilakukan di UPT Perpustakaan Universitas Jember menghasilkan temuantemuan seperti yang tercantum di tabel. Temuan-temuan tersebut dapat dikategorikan menjadi tiga, antara lain (Wahyudin.2013. "Klasifikasi Temuan Audit" (online), (https://abunajmu.wordpress.com/2011/07/08/klasifikasitemuan-audit/ ), diakses tanggal 4 Agustus 2016) :

\section{a. Observasi}

Temuan dapat dikategorikan sebagai observasi jika temuan tersebut tidak bisa dimasukkan dalam kategori ketidaksesuaian, tidak melanggar dokumentasi sistem manajemen yang ditetapkan

b. Minor

Temuan dapat dikategorikan sebagai minor jika temuan tidak berdampak serius terhadap mutu proses dan produk dan karena adanya kesalahan yang dilakukan manusia.

c. Mayor

Temuan dapat dikategorikan sebagai mayor jika temuan tersebut berdampak serius terhadap efektifitas sistem mutu.

\section{Pembahasan}

Setelah melakukan penelitian mengenai audit kualitas di UPT Perpustakaan Universitas Jember dan menemukan berbagai temuan, maka peneliti memberikan rekomendasi untuk meningkatkan pengelolaan SMM ISO 9001:2008 dan mewujudkan perbaikan berkelanjutan. Rekomendasi telah disusun sesuai bidangnya masing-masing, antara lain:

\section{Bidang Pembinaan Koleksi}

\section{a. Klausul 4 :}

Perpustakaan sudah menyusun pedoman mutu dengan baik dan telah mengacu SMM ISO 9001:2008, dokumen-dokumen yang ada di dalamnya relevan dengan SMM ISO 9001:2008 sehingga pelayanan yang diberikan telah cukup 
mencerminkan pelayanan yang berpusat kepada kebutuhan dan kepuasan pemustaka. Revisi mengenai apa yang ada di pedoman mutu harus selalu dilakukan berdasarkan hasil audit internal. Hal ini untuk memastikan bahwa aspek-aspek yang berada di dalam pedoman mutu masih relevan.

\section{b. Klausul 5 :}

Sosialisasi mengenai apa itu pedoman mutu, kebijakan mutu, dan sasaran mutu harus sering dilakukan untuk mengingatkan kembali pengetahuan ini kepada semua jajaran di perpustakaan. Sosialisasi ini harus dilakukan terjadwal dan secara rutin agar setiap pustakawan mengerti betul mengenai apa yang mereka lakukan dan apa yang seharusnya mereka lakukan berdasarkan standar yang telah disusun.

\section{c. Klausul 6:}

Perpustakaan seharusnya melakukan perbaikan mengenai tata ruang untuk meningkatkan efisiensi interaksi alur proses ouput dan input yang terjadi antar bidang. Dalam hal ini antara bidang Pembinaan Koleksi dan Sirkulasi letaknya seharusnya berdekatan. Terjadwalnya kegiatan pelatihan untuk meningkatkan kompetensi dan profesionalitas pustakawan. Dengan terjadwalnya kegiatan pelatihan maka alokasi anggaran untuk kegiatan tersebut juga terfasilitasi sehingga peningkatan kompetensi untuk pustakawan benarbenar dapat tercapai.

\section{d. Klausul 7 :}

Adanya metode lain untuk menilai kesesuaian proses dan produk yang diberikan selain survey dan kotak saran. Selain itu perlu metode lain untuk menilai apakah kinerja di bidang Pembinaan Koleksi sudah sesuai dengan persyaratan produk dan kebutuhan pemustaka. Untuk memenuhi kebutuhan pemustaka akan bahan pustaka yang diinginkan, perpustakaan dapat membuat sebuah sarana untuk menampung keinginan pemustaka akan bahan pustaka yang diinginkan.

\section{Bidang Sirkulasi}

\section{a. Klausul 4}

Perencanaan dan pelaksanaan sosialisasi yang rutin dan terjadwal di dalam rencana kerja tahunan perpustakaan sehingga sosialisasi tersebut terfasilitasi dengan anggaran dana. Menurut wawancara dengan kepala perpustakaan, sosialisasi SMM ISO 9001:2008 memang sudah pernah dilaksanakan, tapi kegiatan tersebut belum pernah dilakukan kembali sejak sebelum persiapan penerapan SMM ISO 9001:2008 pada tahun 2009. Sosialisasi ini penting untuk dilakukan secara rutin untuk menyadarkan kepada seluruh pegawai di perpustakaan mengenai SMM ISO 9001:2009, pedoman mutu, pentingnya melakukan pelayanan berdasarkan mutu dan lain sebagainya.

\section{b. Klausul 5}

Dilakukan revisi setiap tahun mengenai isi sasaran mutu. Dengan pencapaian predikat ISO 9001:2008, perpustakaan seharusnya dengan telaten mengubah dan memperhatikan pengelolaan sistem manajemen mutu yang diterapkan dan membandingkan isi pedoman mutu dengan kondisi yang ada di perpustakaan dan perkembangan di dunia luar. Mengenai ketidaksesuaian antara realita proses kerja dengan instruksi kerja, kepala bidang Sirkulasi dapat bertindak lebih tegas dan memberikan teguran dan sanksi kepada petugas yang mengabaikan instruksi kerja. Adanya teguran dan sanksi tersebut dapat menyadarkan petugas untuk tetap melayani pemustaka sesuai standar pelayanan, prosedur dan instruksi kerja yang ada. Mengenai proses absensi pemustaka dengan scan KAP seharusnya menggunakan teknologi yang lebih canggih yang dapat memunculkan identitas pemilik KAP dengan jelas agar memudahkan petugas absensi untuk mengenali pemilik KAP dan dapat menolak pemustaka apabila identitas pemilik yang tertera di KAP dengan calon pemustaka berbeda.

\section{c. Klausul 6}

Pemenuhan klausul 6 oleh bagian Sirkulasi sudah dilakukan cukup baik. Sedangkan permasalahan mengenai gedung perpustakaan yang harus berbagi fungsi dengan fakultas Sistem Informasi seharusnya dapat segera ditinjau oleh bagian pusat universitas untuk dapat dipikirkan jalan keluarnya. Kemudian mengenai kerusakan komputer dapat dicegah dengan perawatan yang baik dan rutin oleh bagian Sirkulasi. Bagian Sirkulasi dapat bekerja sama dengan bagian Pengembangan dan Kerjasama untuk menyusun prosedur dan instruksi kerja untuk perawatan sarana dan prasarana elektronik, seperti komputer dan mesin peminjam mandiri. Sedangkan untuk fasilitas CCTV, seharusnya disediakan layar untuk petugas agar fungsi CCTV dapat dengan maksimal difungsikan.

\section{d. Klausul 7}

Dilakukan revisi mengenai formulir saran pemustaka dengan menambahkan bagian pelayanan yang termasuk dalam bidang Sirkulasi, yaitu bagian front office. Adanya ide-ide kreatif untuk menarik pemustaka mengisi formulir saran tersebut. Ide-ide tersebut dapat berupa undian berhadiah kepada pemustaka yang mengisi polling, kritik dan saran di formulir saran pemustaka. Kemudian untuk dibuatnya polling di website resmi perpustakaan atau apabila memungkinkan dibuat kegiatan polling yang menarik perhatian pemustaka di perpustakaan. Kegiatan polling yang menarik ini dapat diwujudkan dengan cara yang tidak konvensional, akan tetapi secara online yaitu melalui komputer di pintu keluar gedung perpustakaan.

\section{Bidang Pengembangan dan Kerjasama}

\section{a. Klausul 4}

Perlunya diadakan rapat mengenai revisi isi pedoman mutu dan untuk menyusun sasaran mutu dan standar pelayanan untuk bidang Pengembangan dan Kerjasama agar ada tujuan yang jelas yang ingin dicapai. Sehingga kinerja yang dihasilkan tidak konstan tapi dapat meningkat.

\section{b. Klausul 5}

Diadakan sosiaslisasi mengenai SMM ISO 9001:2008 agar semua jajaran yang ada di perpustakaan mengerti betul mengenai apa itu kebijakan mutu, sasaran mutu, isi dari pedoman mutu, manfaat mengadopsi SMM ISO 9001:2008 dan apa kontribusi mereka untuk mencapai sasaran mutu yang telah ditetapkan.

\section{c. Klausul 6}

Bidang ini membutuhkan lebih banyak personil karena beban pekerjaan yang sangat banyak. Perpustakaan dapat membuka 
lowongan pekerjaan untuk mencari SDM yang berkualitas yang dapat dipekerjakan di bidang ini. Selanjutnya menurut penulis, bidang ini bisa dipecah kembali agar fokus yang dikerjakan tidak terlalu banyak . Bidang Pengembangan dan Kerjasama dapat berfokus kepada hal-hal yang berkaitan dengan pengembangan pustakawan, sarana dan prasarana perpustakaan dan kerjasama dengan berbagai pihak di luar perpustakaan. Kemudian untuk urusan IT dibuat satu bidang tersendiri untuk mengurus hal tersebut sehingga apabila ada trouble yang berkaitan karena IT bukan bidang pengembangan dan kerjasama yang mengurusnya akan tetapi bidang IT yang mengurus. Begitupula dengan proses perbaikan website dan berbagai hal yang dapat memajukan perpustakaan dengan IT dapat dilakukan oleh bidang ini.

\section{d. Klausul 7}

Kesesuaian proses dan produk yang dihasilkan dapat dilakukan jika sudah ada sasaran mutu dan persyaratan produk. Sehingga menurut penulis, rekomendasi untuk bidang ini adalah disusunnya sasaran mutu dan standar pelayanan untuk bidang Pengembangan dan Kerjasama agar nantinya dapat dilakukan verifikasi dan validasi mengenai kesesuaian proses dan produk.

\section{Bidang Layanan Perujukan dan Koleksi Khusus}

\section{a. Klausul 4}

Ketua Gugus Penjamin Mutu (GPM) dan Kepala Bidang Layanan Perujukan dan Koleksi Khusus harus merevisi kembali isi pedoman mutu yaitu isi sasaran mutu. Sasaran mutu sebaiknya direvisi dengan ditambahkan tujuan yang ingin dicapai oleh bidang ini sehingga bidang Layanan Perujukan dan Koleksi Khusus mempunyai arah dan tujuan yang jelas yang ingin dicapai. Apabila tidak ada tujuan, maka pelayanan yang diberikan cenderung hanya asal melayani saja dan tidak akan berkembang dan berusaha untuk menjadi lebih baik.

\section{b. Klausul 5}

Disarankan agar isi sasaran mutu ditambah sehingga nantinya dapat dibuat program kerja untuk mencapai sasaran mutu. Dengan adanya sasaran mutu dan program kerja maka kerja dari bidang ini terencana dengan baik. Apabila suatu rencana disusun dengan baik dan detail maka akan lebih mudah untuk merealisasikan rencana tersebut. Direncanakan dan diadakan sosialisasi mengenai ISO 9001:2008, mengapa kita mengadopsi sistem tersebut, isi pedoman mutu, manfaat ISO dan lain sebagainya untuk mengingatkan kembali kepada semua jajaran di perpustakaan untuk tetap melayani pemustaka berdasarkan standar yang telah ditetapkan.

\section{c. Klausul 6}

Ditambahkan koleksi-koleksi khusus yang sesuai dengan minat sebagian besar mahasiswa dan koleksi-koleksi yang cocok dengan isu-isu yang terjadi sekarang untuk menarik lebih banyak minat pemustaka. Seharusnya jika proses absensi masih dilakukan manual, bidang ini dapat memberitahukan bidang Pengembangan dan Kerjasama untuk mengautomasi proses absensi bidang ini (dengan komputer). Diadakan refleksi dengan semua petugas di bidang ini untuk meningkatkan kinerja yang telah mereka hasilkan menjadi lebih baik lagi. Dari refleksi ini diharapkan akan mendapatkan saran dan kritik yang membangun untuk masa depan bidang Layanan Perujukan dan Koleksi Khusus.

\section{d. Klausul 7}

Disusun kembali sasaran mutu dengan menambahkan sasaran mutu untuk bidang ini dan menambahkan standar pelayanan yang bisa diaplikasikan di bidang Layanan Perujukan dan Koleksi Khusus agar proses yang terjadi dan produk yang dijanjikan sesuai. Kemudian diberikannya perhatian lebih kepada metode berkomunikasi dengan pemustaka yang selama ini dimiliki, yaitu kotak saran. Form yang dibagikan dapat diubah menjadi lebih menarik dan praktis, yaitu dengan membuat polling yang ringkas. Selain itu dapat juga diadakan event kreatif yang dapat mendorong minat pemustaka untuk mengisi polling dan memberikan saran yang bermanfaat bagi perpustakaan, khususnya bidang ini.

\section{Kepala Gugus Penjamin Mutu Perpustakaan}

\section{a. Klausul 4}

Perpustakaan telah menetapkan dokumentasi SMM ISO 9001:2008 yang dibutuhkan. Akan tetapi sasaran mutu saat ini hanya tersedia untuk dua bidang yaitu bidang Pembinaan Koleksi dan bidang Sirkulasi. Sedangkan dua bidang lainnya tidak mempunyai sasaran mutu dan pengetahuan akan hal tersebut juga sangat minim. Oleh sebab itu direkomendasikan untuk merevisi isi pedoman mutu dan menyusun sasaran mutu untuk kedua bidang tersebut.

\section{b. Klausul 5}

Pentingnya untuk menyusun kembali sasaran mutu perpustakaan dan menambahkan sasaran mutu untuk kedua bidang yang belum mempunyai sasaran mutu tersebut, Selain itu perlu diadakannya sosialisasi mengenai SMM ISO 9001:2008 untuk mengingatkan kembali alasan mengadopsi sistem tersebut, manfaat menggunakan sistem tersebut dan isi pedoman mutu.

\section{c. Klausul 6}

Tersedianya sarana dan prasarana yang memadai juga membutuhkan perawatan yang maksimal dengan sumber daya manusia yang kompeten untuk melaksanakan perawatan tersebut. Akan tetapi berdasarkan pengamatan peneliti, sarana seperti mesin peminjam mandiri dan komputer di bidang Sirkulasi sering mengalami kerusakan. Setelah ditelusuri penyebab dari kerusakan sarana tersebut karena kurangnya personil yang ada untuk menjaga dan merawat sarana dan prasarana elektronik di perpustakaan. Perpustakaan membutuhkan lebih banyak lagi personil untuk bertanggung jawab dalam hal ini. Personil yang bertanggung jawab dalam hal ini adalah bidang Pengembangan dan Kerjasama sehingga bidang inilah yang sangat membutuhkan lebih banyak personil. Dari temuan ini, perpustakaan dapat membuka lowongan kerja untuk memenuhi kekurangan personil di bidang Pengembangan dan Kerjasama.

\section{d. Klausul 7}

Ditambahkan metode efektif untuk pemustaka agar dapat berkomunikasi dengan perpustakaan, karena metode ini dinilai kurang efektif dan praktis. Metode komunikasi yang bisa ditambahkan sebagai sarana berkomunikasi pemustaka dan perpustakaan dapat berupa polling elektronik yang disediakan di pintu keluar perpustakaan dan website resmi 
perpustakaan untuk menilai tingkat kepuasan pelayanan yang didapatkan pemustaka.

\section{e. Klausul 8}

Adanya metode lain yang lebih efektif untuk memantau dan mengukur ketidaksesuaian produk dan proses selain kotak saran dan laporan kesesuaian yang dilakukan sekretaris GPM.

\section{Simpulan}

Pihak yang mengawasi dan mengelola sistem manajemen mutu di UPT Perpustakaan Universitas Jember adalah Kepala Gugus Penjamin Mutu Perpustakaan. Aktivitas pengelolaan SMM ISO 9001:2008 di UPT Perpustakaan sudah diterapkan dengan cukup efektif namun masih membutuhkan perhatian dan beberapa revisi di dalam pedoman mutu, misalnya penambahan sasaran mutu untuk bagian Pengembangan dan Kerjasama dan bagian Layanan Perujukan dan Koleksi Khusus.

Perpustakaan sudah menyusun pedoman mutu dengan baik dan telah mengacu SMM ISO 9001:2008, dokumen-dokumen yang ada di dalamnya relevan dengan SMM ISO 9001:2008 sehingga pelayanan yang diberikan telah cukup mencerminkan pelayanan yang berpusat kepada kebutuhan dan kepuasan pemustaka. Revisi mengenai apa yang ada di pedoman mutu harus selalu dilakukan berdasarkan hasil audit internal. Hal ini untuk memastikan bahwa aspek-aspek yang berada di dalam pedoman mutu masih relevan.

Perencanaan dan pelaksanaan sosialisasi yang rutin dan terjadwal di dalam rencana kerja tahunan perpustakaan sehingga sosialisasi tersebut terfasilitasi dengan anggaran dana. Menurut wawancara dengan kepala perpustakaan, sosialisasi SMM ISO 9001:2008 memang sudah pernah dilaksanakan, tapi kegiatan tersebut belum pernah dilakukan kembali sejak sebelum persiapan penerapan SMM ISO 9001:2008 pada tahun 2009. Sosialisasi ini penting untuk dilakukan secara rutin untuk menyadarkan kepada seluruh pegawai di perpustakaan mengenai SMM ISO 9001:2009, pedoman mutu, pentingnya melakukan pelayanan berdasarkan mutu dan lain sebagainya.

Ketua Gugus Penjamin Mutu (GPM) dan Kepala Bidang Layanan Perujukan dan Koleksi Khusus harus merevisi kembali isi pedoman mutu yaitu isi sasaran mutu. Sasaran mutu sebaiknya direvisi dengan ditambahkan tujuan yang ingin dicapai oleh bidang ini sehingga bidang Layanan Perujukan dan Koleksi Khusus mempunyai arah dan tujuan yang jelas yang ingin dicapai. Apabila tidak ada tujuan, maka pelayanan yang diberikan cenderung hanya asal melayani saja dan tidak akan berkembang dan berusaha untuk menjadi lebih baik.

Audit sistem kepastian kualitas yang dilakukan di UPT Perpustakaan Universitas Jember untuk menilai efektivitas penerapan SMM ISO 9001:2008 menghasilkan beberapa temuan minor dan mayor. Temuan minor didapati di bidang Pembinaan Koleksi dan dari bidang Gugus Penjamin Mutu. Sedangkan temuan mayor ditemui dari bidang Sirkulasi, bidang Pengembangan dan Kerjasama dan bidang Layanan Perujukan dan Koleksi Khusus.

Rekomendasi yang dapat diberikan berdasarkan hasil audit kepastian kualitas di UPT Perpustakaan Universitas Jember antara lain adalah :

Revisi pedoman mutu yaitu penyusunan sasaran mutu untuk bidang Pengembangan dan Kerjasama dan bidang Layanan Perujukan dan Koleksi Khusus. Kemudian perencanaan pelaksanaan sosialisasi SMM ISO 9001:2008 yang rutin. Automasi kegiatan yang masih dilakukan dengan proses manual. Pemaksimalan teknologi yang tersedia. Perbaikan metode berkomunikasi dengan pemustaka menjadi lebih kreatif. Penambahan personil untuk bagian Pengembangan dan Kerjasama.

\section{Referensi}

Bhayangkara, IBK, "Audit Manajemen: Prosedur dan Implementasi" Cetakan ketujuh, Salemba Empat, Jakarta, 2014

Hasan, M. Iqbal, Pokok-Pokok Materi Metodologi Penelitian dan Aplikasinya, Ghalia Indonesia, Bogor, 2002.

Indriantoro, Nur dan Bambang Supomo, 2009, "Metodologi Penelitian Bisnis untuk Akuntansi dan Manajemen", Edisi Pertama, BPFE,Yogyakarta

Moleong, Lexi J. "Metodologi Penelitian Kualitatif," Remaja Rosdakarya, Jakarta 2015

Wahyudin. 2013. “Klasifikasi Temuan Audit”(online), (https://abunajmu.wordpress.com/2011/07/08/klasifikasi-temuan-audit/ ), diakses tanggal 4 Agustus 2016). 